\title{
PENGGUNAAN USABILITY TESTING SEBAGAI ALAT EVALUASI WEBSITE KRS ONLINE PADA PERGURUAN TINGGI
}

\author{
Pristi Sukmasetya ${ }^{1}$ Agus Setiawan ${ }^{2}$ Endah Ratna Arumi ${ }^{3}$ \\ 1,2,3Teknik Informatika, Universitas Muhammadiyah Magelang \\ Magelang, Indonesia
}

e-mail: pristi.sukmasetya@ummgl.ac.id ${ }^{1}$, setiawan@ummgl.ac.id², arumi@ummgl.ac.id³

\begin{abstract}
Abstrak
Website KRS Online adalah salah satu sistem yang ada di Universitas Muhammadiyah Magelang yang digunakan oleh civitas akademia (termasuk dosen, mahasiswa dan tenaga kependidikan) untuk merekap data akademik mahasiswa dalam jumlah yang tidak sedikit. Untuk mengetahui seberapa jauh efektif dan efisiennya dari sistem tersebut maka perlu dilakukan evaluasi. Evaluasi yang dilakukan pada penelitian ini menggunakan usability testing dengan menggunakan lima kategori yaitu learnability, memorability, efficiency, errors, dan satisfaction. Kelima indikator tadi direpresentasikan dalam bentuk pernyataan kuesioner dan disebarkan secara daring kepada pengguna Website KRS Online. Adapun total sampel responden adalah sejumlah 118 orang. Metode uji yang digunakan pada penelitian ini meliputi uji validitas yang terdiri dari uji reliabilitas dan uji korelasi. Signifikansi nilai Alpha yang digunakan pada penelitian ini sebesar 0,05. Dari hasil uji validitas data yang dilakukan, seluruh indikator memiliki nilai diatas 0,05 . Dari hasil uji reliabilitas seluruh pernyataan yang ada pada kuesioner juga memiliki nilai Cronbach's Alpha sebesar 0.93, yang berarti seluruh pernyataan sesuai. Hasil evaluasi menunjukkan bahwa pada Website KRS Online memiliki nilai paling tinggi pada indikator memorability sebesar 3.97 ini berarti bahwa Website KRS Online mudah diingat navigasi dan tata letaknya untuk mendapatkan informasi. Sedangkan untuk nilai terendah dari kelima indikator adalah pada indikator error dengan nilai sebesar 3 ini berarti bahwa pada Website KRS Online masih ditemukan banyak kesalahan atau error baik itu pada brokenlink, atau pada navigasi yang ada.
\end{abstract}

Kata kunci: Usability, Usability Testing, Usability Evaluation

\begin{abstract}
The Online KRS Website is one of the existing systems at the University of Muhammadiyah Magelang that is used by the academics (including lecturers, students and education staff) to recap the amount of student academic data in large amounts. To find out how far effective and efficient the system is, an evaluation is needed. The evaluation conducted in this study uses usability testing using five categories, namely learnability, memorability, efficiency, errors, and satisfaction. The five indicators are represented in the form of questionnaire statements and distributed Online to KRS Website users Online. The total sample of respondents was 118 people. The test method used in this study includes a validity test consisting of a reliability test and a correlation test. The significance of the Alpha value used in this study was 0.05 . From the results of the data validity test conducted, all indicators have values above 0.05 . From the reliability test results, all statements contained in the questionnaire also have a Cronbach's Alpha value of 0.93, which means that all statements are in accordance. The evaluation results show that the KRS Online Website has the highest value on the memorability indicator of 3.97 this means that the KRS Online Website is easy to remember navigation and its layout to get information. While for the lowest value of the five indicators is the error indicator with a value of 3 this means that the KRS Online Website is still found many errors or errors either on the broken link, or on the existing navigation.
\end{abstract}

Keywords : Usability, Usability Testing, Usability Evaluation 


\section{PENDAHULUAN}

Perkembangan internet dan teknologi informasi kali ini, menjadikan banyak peluang dari berbagai macam sektor (Azzahra, 2018) dan memberikan banyak kebermanfaatan (Binti \& Rozali, 2015). Tidak hanya memberikan peluang pada sektor barang dan jasa, akan tetapi internet dan teknologi informasi memberikan banyak kebermanfaatan pada sektor pendidikan(Al-omar, 2018).

Tidak hanya itu saja, teknologi banyak digunakan untuk membantu kegiatan sehari-hari. Terutama dalam teknologi informasi, karena dengan berkembangnya teknologi informasi (TI) kegiatan sehari-hari dapat dilakukan dengan efisien, efektif dan akurat, sehingga dapat meningkatkan produktivitas. TI tidak hanyak berfokus ke teknologi komputer saja yang digunakan untuk mengolah dan menyimpan informasi, melainkan juga dalam teknologi komunikasi untuk mengirimkan informasi. Dalam perkembangannya dikenal dengan revolusi industri, dan menurut (Al Faruqi, 2019) European Parliamentary Research Service revolusi industri sudah terjadi sebanyak empat kali. Bahkan jepang sudah memasuki era society 5.0 yang memiliki definisi $A$ human-centered society that balances economic advancement with the resolution of social problems by a system that highly integrates cyberspace and physical space. Di Indonesia sendiri sekarang sudah memasuki revolusi industri 4.0, dimana semua kebutuhan berkaitan dengan teknologi dan internet di segala bidang. Perkembangan teknologi itu sudah memicu terlahirnya electronic-life yang diartikan semua kegiatan sudah bergantung dengan elektronik. Beberapa kegiatannya antara lain, e-commerce, e-education, ejournal, e-transportation dan masih banyak lagi .

Salah satu pemanfaatan teknologi informasi dan komunikasi yang ada dan sudah banyak dimanfaatkan pada sektor pendidikan terlebih untuk perguruan tinggi dan pemerintahan (Setiawan et al., 2018; Sukmasetya, Santoso, \& Sensuse, 2018). Salah satu pemanfaatan teknologi informasi dan komunikasi di perguruan tinggi adalah dengan adanya Website KRS Online yang memudahkan mahasiswa dan dosen dalam melakukan tracking kegiatan akademik yang berlangsung pada perguruan tinggi. Berdasarkan manfaat yang diperoleh dengan keberadaan Website KRS Online ini, maka sudah selayaknya perguruan tinggi melakukan pengembangan dan pemeliharaan pada Website KRS Online yang ada secara maksimal. Namun pada kenyataannya, masih jarang perguruan tinggi yang mau mengeluarkan usaha lebih untuk melakukan evaluasi terhadap teknologi informasi (Mustafa \& Al-Zoua'bi, 2008), aplikasi maupun situs Website yang dimiliki (Sensuse, Pudy, \& Sukmasetya, 2017) seperti Website KRS Online itu sendiri. Menjadi penting untuk melakukan evaluasi ini, mengingat Website KRS Online sebagai salah satu Website yang sering digunakan oleh civitas akademia (baik itu mahasiswa, dosen, tenaga kependidikan) untuk merekam jejak akademik mahasiswa dengan jumlah data yang tidak sedikit (Setiawan et al., 2018). Evaluasi ini nantinya akan berguna untuk mengetahui seberapa efektif dan efisiennya (Zarish, 2019) dari Website KRS Online tersebut bagi pengguna. Evaluasi ini juga akan sangat bermanfaat, sebagai salah satu dasar pengembangan situs web yang dimiliki, apabila nanti kedepannya akan menambahkan beberapa fitur. (Luo, Wang, Wang, \& Participants, 2018; Huang \& Li, 2010) Evaluasi yang bisa dilakukan utnuk mengetahui sejauh apa pemanfaatan sebuah teknologi atau aplikasi dijalankan salah satunya adalah menggunakan analisis usability.

Usability merupakan bagian dari keilmuan Human Computer Interaction. yang fokus mempelajari design antarmuka dan interaksi antara manusia dengan komputer (Binti \& Rozali, 2015)(Al-omar, 2018). Kajian usability ini akan membahas tentang pengalaman pengguna dalam mempelajari dan menggunakan teknologi, aplikasi atau situs web tertentu (Sauer et al., 2019). Indikator yang ada pada usability juga digunakan untuk mengukur seberapa puas pengguna dalam menggunakan teknologi, aplikasi, atau produk tersebut untuk mencapai goals atau tujuan, dalam hal ini ukuran keberhasilannya dapat 
dilihat dari seberapa baik sebuah aplikasi atau teknologi dalam memberikan kualitas layanan kepada pengguna (Qashlim, Prahasto, \& Gernowo, 2014). Tidak hanya itu saja tetapi juga seberapa jauh aplikasi atau teknologi dapat mengurangi kemungkinan kesalahan yang terjadi sehingga didapatkan proses pembelajaran dalam menggunakan aplikasi dengan mudah.

Ada lima indikator (Setiawan et al., 2018;Kaur, 2018) yang terdapat pada usability dan bisa digunakan untuk mengetahui kualitas sebuah Website dalam berinteraksi dengan penggunanya. Kelima indikator tersebut, yang pertama adalah Learnability. Learnability ini salah satu indikator pada usability yang digunakan untuk mengetahui seberapa mudah pengguna dalam mempelajari Website yang digunakan dalam memenuhi task yang ada. Indikator yang kedua adalah memorability. Memorability adalah indikator yang digunakan untuk mengetahui sejauh apa kemudahan pengguna mengingat cara menggunakan Website apabila setelah sekian lama tidak menggunakannya. Selanjutnya, Efficiency adalah indikator yang digunakan untuk mengetahui seefisien apa para pengguna dalam melakukan beberapa task yang tersedia pada aplikasi. Errors adalah indikator yang dipakai untuk mengetahui seberapa banyak kesalahan yang dilakukan oleh pengguna ketika menggunakan Website, dan berkaitan dengan cara pengguna dalam memperbaiki kesalahan. Satisfaction adalah indikator yang menjelaskan tingkat kepuasan pengguna dalam menggunakan Website.

\begin{tabular}{llr}
\multicolumn{1}{c}{ Beberapa } & penelitian & yang \\
mencobakan & evaluasi & Website \\
menggunakan usability & menunjukkan \\
bahwa usability mampu & menjabarkan \\
secara lebih rinci terkait & pengalaman
\end{tabular} pengguna dalam menggunakan aplikasi atau sistem tertentu. Tentunya beberapa hal yang diuntungkan dengan mengetahui kondisi pengalaman dan kepuasan pengguna dalam memakai aplikasi atau sistem diantaranya adalah mampu meningkatkan efisiensi dari sistem itu sendiri (Zhevlwh et al., 2016; Qiu, Chui, \& Helander, 2006). Dari sisi tampilan pun, apabila design tampilan dari aplikasi lebih user friendly dan mudah digunakan maka pengguna tidak perlu menghabiskan banyak waktu hanya sekedar untuk memahami dan berulang kali memastikan maksud dari tampilan yang ada pada aplikasi atau sistem tersebut.

Manakala perangkat lunak tidak memenuhi kriteria usability, pengguna akan menghabiskan waktu terlalu banyak untuk memahami antar muka, sehingga membuat mereka menjadi kurang efisien dalam bekerja. Meningkatnya produktivitas. Tampilan antar muka yang usable membuat pengguna bisa lebih berkonsentrasi pada pekerjaan mereka alih-alih pada perangkat yang mereka gunakan. Pelatihan yang lebih sedikit. Oleh karenanya, waktu dan biaya bisa terkurangi. Produk yang usable juga akan menjadikan masalah yang dialami pengguna berkurang, dan karena-nya, dukungan terhadap produk juga bisa berkurang. Meningkatnya penerimaan (Binti \& Rozali, 2015). Ketika pengguna menyukai sistemnya karena sifatnya yang usable, mereka akan lebih berkenan dalam menggunakannya. Mengurangi biaya pengembangan. Membuat perubahan sejak awal di daur hidup desain jauh lebih murah daripada membuatnya di akhir. Meningkatnya penjualan. kebergunaan dari sebuah sistem bisa menjadi sebuah daya saing unggulan bila dibandingkan dengan produk-produk lain. Untuk itu fokus penelitian ini adalah mengevaluasi Website KRS Online yang ada pada perguruan tinggi dengan usability testing dan in depth interview untuk mengetahui sejauh mana kebergunaan dari sistem tersebut.

\section{METODE PENELITIAN}

Pada penelitian ini, yang akan dijadikan objek adalah situs KRS Online milik Universitas Muhammadiyah Magelang (krsol.ummgl.ac.id). Adapun penelitian yang akan dilakukan dalam hal ini adalah gabungan penelitian kualitatif dan kuantitatif (mix method) dengan menggunakan lima indikator yang ada pada usability testing. Ada empat tahapan yang dilakukan untuk 
melaksanakan metode ini yaitu eksplorasi

konsep dan identifikasi masalah, pengumpulan data, analisis data dan yang terakhir adalah hasil dan pembahasan.

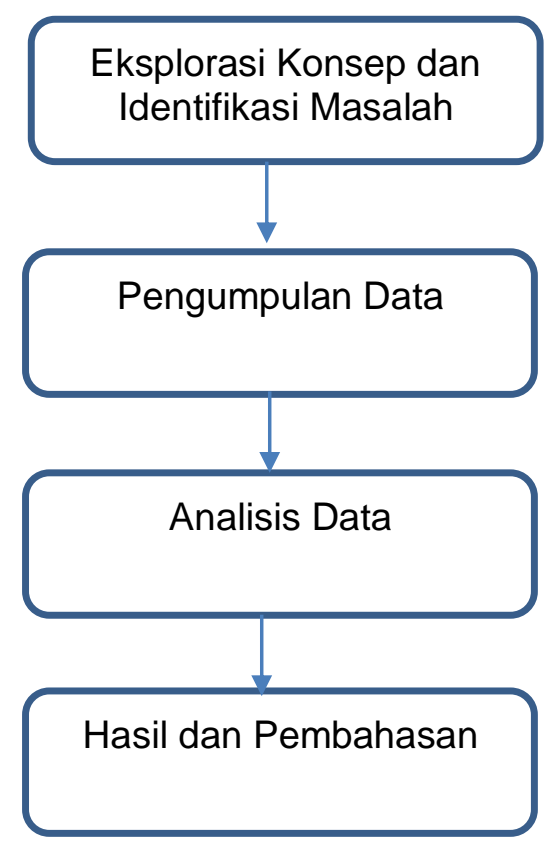

Gambar 1 Tahapan Penelitian

\section{a. Eksplorasi Konsep dan Identifikasi Masalah}

Pada tahapan awal penelitian, eksplorasi konsep dan identifikasi masalah dilakukan dengan studi literatur terkait konsep yang akan digunakan pada penelitian ini. Adapun studi literatur yang dicari sebagai penguat konsep meliputi usability, evaluasi usability, usability testing, pengalaman pengguna Website dan hal-hal yang berkaitan dengan human computer interaction. Hasil studi literatur ini nantinya akan digunakan untuk memperkuat konsep dasar yang akan dijadikan acuan untuk proses analisis data dan mengidentifikasi permasalahan yang ada.

\section{A. Pengumpulan Data}

Pada tahap pengumpulan data, hal pertama yang dilakukan adalah dengan membuat instrumen penelitian. Pada penelitian ini instrumen penelitian yang dibuat berupa kuesioner dengan menurunkan item-item pernyataan dari kelima indikator yang ada pada usability testing. Kelima indikator yang digunakan adalah learnability, memorability, efficiency, errors, dan satisfaction. Dari kelima indikator ini akan diturunkan menjadi beberapa item pernyataan untuk tiap indikatornya yang mewakili pengalaman pengguna dalam menggunakan Website KRS Online. Kuesioner ini akan disebarkan dengan pendekatan purposive sampling pada civitas akademia Universitas Muhammadiyah Magelang yang menggunakan Website KRS Online.

Tabel 1 menjelaskan terkait pengkodean dan butir pernyataan yang diturunkan dari kelima indikator usability testing. Pada penilaiannya, instrument ini menggunakan Skala Likert, dengan lima pilihan respon yaitu sangat tidak setuju (STS), tidak setuju (TS), netral (N), setuju (S), sangat setuju (SS), dengan range skor pada item positif adalah 1-5. Selain dari kuesioner, data tambahan juga akan diambil melalui serangkaian wawancara ke beberapa pakar IT untuk memperkuat hasil evaluasi dari Website KRS Online yang didapatkan melalui kuesioner. Gambar 2 menunjukkan tampilan awal pada Website KRS Online. 
Tabel 1. Pengkodean dan Butir Pernyataan Kuesioner

\begin{tabular}{|c|c|c|}
\hline Indikator & Kode & Pernyataan pada Kuesioner \\
\hline \multirow[t]{5}{*}{ Learnability $(\mathrm{A})$} & (A1) & Website KRS Online dapat dipelajari dengan mudah \\
\hline & (A2) & $\begin{array}{l}\text { Saya dengan mudah dan cepat menerima informasi secara detail dan } \\
\text { juga spesifik pada KRS Online }\end{array}$ \\
\hline & (A3) & $\begin{array}{l}\text { Saya mampu dengan mudah memahami isi dan konten informasi yang } \\
\text { disajikan pada Website KRS Online }\end{array}$ \\
\hline & (A4) & $\begin{array}{l}\text { Saya mampu dengan mudah memahami dan mengerti alur dari } \\
\text { navigasi yang ada pada Website KRS Online }\end{array}$ \\
\hline & (A5) & $\begin{array}{l}\text { Tanpa instruksi tertulis atau manual book, saya mampu mempelajari } \\
\text { penggunaan Website KRS Online }\end{array}$ \\
\hline \multirow[t]{3}{*}{ Memorability (B) } & (B1) & $\begin{array}{l}\text { Saya dapat dengan mudah mengingat penggunaan Website KRS } \\
\text { Online }\end{array}$ \\
\hline & (B2) & $\begin{array}{l}\text { Saya dapat dengan mudah mengetahui dan mengingat arah navigasi } \\
\text { dan fitur pada Website KRS Online }\end{array}$ \\
\hline & (B3) & Saya merasa mudah kapanpun menggunakan Website KRS Online \\
\hline \multirow[t]{3}{*}{ Efficiency (C) } & (C1) & $\begin{array}{l}\text { Saya mampu melakukan akses menu pada Website KRS Online } \\
\text { dengan cepat }\end{array}$ \\
\hline & (C2) & $\begin{array}{l}\text { Saya dengan mudahnya memperoleh informasi yang ada terkait } \\
\text { Website KRS Online }\end{array}$ \\
\hline & $(\mathrm{C} 3)$ & $\begin{array}{l}\text { Saya mampu langsung menemukan informasi yang saya ingin cari } \\
\text { dari awal membuka pada Website KRS Online }\end{array}$ \\
\hline \multirow[t]{3}{*}{ Errors (D) } & (D1) & $\begin{array}{l}\text { Saya tidak menemukan error disaat menggunakan Website KRS } \\
\text { Online }\end{array}$ \\
\hline & (D2) & $\begin{array}{l}\text { Saya tidak menemukan menu yang error atau tidak sesuai dengan } \\
\text { fungsinya }\end{array}$ \\
\hline & (D3) & $\begin{array}{l}\text { Saya dapat menemukan fitur dan menu yang saya cari pada Website } \\
\text { KRS Online }\end{array}$ \\
\hline \multirow[t]{3}{*}{ Satisfaction (E) } & $(\mathrm{E} 1)$ & $\begin{array}{l}\text { Saya senang dengan design antarmuka yang ada pada Website KRS } \\
\text { Online secara keseluruhan }\end{array}$ \\
\hline & $\begin{array}{l}(\mathrm{E} 2) \\
(\mathrm{E} 3)\end{array}$ & $\begin{array}{l}\text { Saya merasa nyaman dalam menggunakan Website KRS Online } \\
\text { Paduan warna dan tata letak konten nyaman untuk dilihat }\end{array}$ \\
\hline & (E4) & $\begin{array}{l}\text { Website KRS Online sesuai dengan ekspektasi saya, ketika saya } \\
\text { melihat judul yang ada pada laman sistem tersebut }\end{array}$ \\
\hline
\end{tabular}

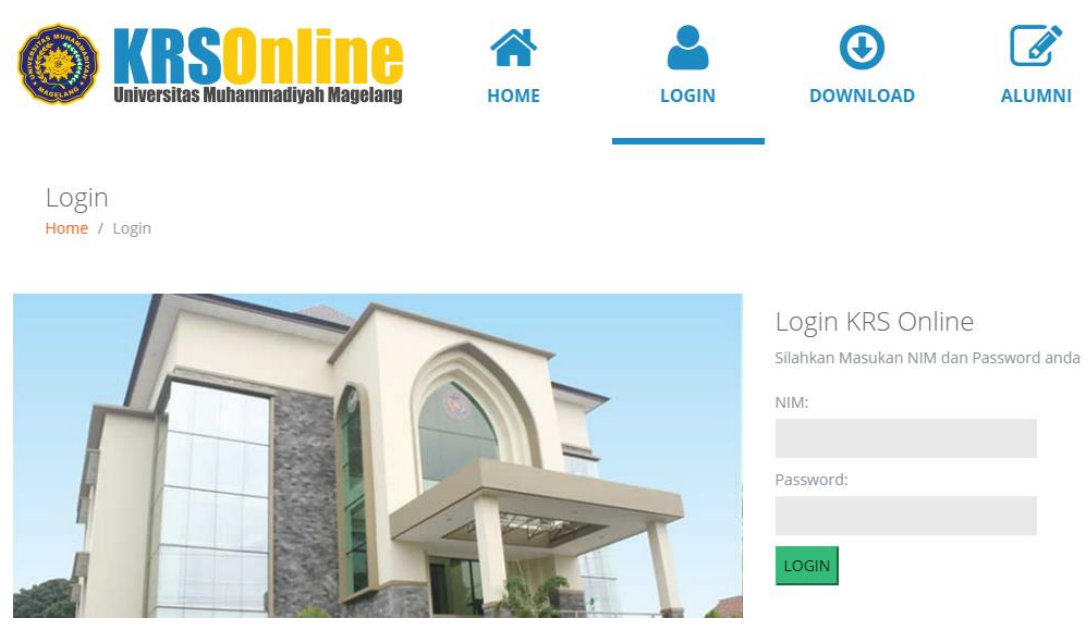

Gambar 2 Tampilan Website KRS Online

\section{B. Analisis Data}

Tidak hanya pertanyaan dengan pilihan skala likert saja yang diberikan kepada responden. Akan tetapi beberapa butir pertanyaan terbuka juga disertakan. Hal ini bertujuan untuk mengetahui lebih 
lanjut perihal pengalaman pengguna dalam menggunakan Website KRS Online ini. Ada lima pertanyaan terbuka yang masing-masing mewakili kelima indikator usability testing yang ada. Tidak lupa, dilakukan uji keterbacaan terlebih dahulu untuk kuesioner yang akan didistribusikan pada responden. Uji keterbacaan ini dilakukan dengan mengambil sepuluh orang yang nantinya akan menjadi responden dalam penelitian ini. Hal ini bertujuan untuk menghindari ketidakpahaman responden terhadap pernyataan yang akan diajukan.

Untuk selanjutnya analisis data yang akan digunakan dalam penelitian ini adalah dengan menggunakan pendekatan mix method atau gabungan dari analisis data kuantitatif dan kualitatif. Untuk analisis kuantitatif, menggunakan analisis statistik deskriptif yang bertujuan untuk mengetahui rata-rata hasil evaluasi dari kelima indikator yang ada pada usability testing pada Website KRS Online. Untuk analisis kualitatif, dilakukan dengan melakukan transcribing hasil dari pertanyaan terbuka yang disertakan pada kuesioner pengguna Website KRS Online dan mengolahnya dengan Tools NVIVO.

\section{HASIL DAN PEMBAHASAN}

\section{A. Hasil Eksplorasi Konsep dan Identifikasi Masalah}

Langkah pertama yang dilakukan adalah memilih beberapa studi yang berkaitan dengan konsep-konsep yang akan digunakan dalam penelitian ini dengan mencari dan mengambil dari beberapa artikel jurnal dan makalah konferensi dari database yaitu IEEE Xplorer, ACM Digital Library, AIS Electronic Library, Emerald Insight, ProQuest, dan ScienceDirect / Scopus. Hal ini bertujuan untuk mendapatkan lebih banyak pemahaman tentang usability testing dan permasalahan yang ada. Dari hasil pencarian kami menemukan hampir sebelas makalah yang menunjukkan konsep pengujian kegunaan dan wawancara mendalam dan bagaimana yang harus kita lakukan untuk menyelesaikan masalah.

\section{B. Hasil Uji Reliabilitas dan Uji Validitas}

Dalam penyebaran kuesioner, peneitian ini menggunakan metode purposive sampling (Tongco, 2007) untuk mendapatkan responden. Yang berarti, peneliti menentukan syarat terlebih dahulu terkait responden yang dituju. Adapun syarat yang diberlakukan pada penelitian ini yaitu, para pengguna KRS Online dalam hal ini mahasiswa UMMagelang. Sebelum kuesioner disebarkan, terlebih dahulu dilakukan dua pengujian. Yaitu Uji Validitas dengan menggunakan uji keterbacaan yang dilaksakanan dengan cara memilih sepuluh calon responden secara acak, untuk melihat sejauh apa pernyataan yang ada pada kuesioner dapat dipahami oleh calon responden. Selanjutnya, Uji Reliabilitas dilakukan reliable atau tidaknya draft kuesioner yang akan disebarkan. Dalam melakukan Uji Reliabilitas, menggunakan bantuan tools SPSS.

Tabel 2. Hasil Uji Reliabilitas Instrumen Kuesioner

\begin{tabular}{cccc}
\hline Cronbach's Alpha & Cronbach's Alpha Based on Standardized Items & N of ltems \\
\hline 0,934 & 0,936 & 18 \\
\hline
\end{tabular}

Tabel 2 menunjukkan hasil dari uji reliabilitas yang dilakukan, dari uji tersebut didapatkan bahwa cronbach's alpha sebesar 0.934 yang berarti bahwa pernyataan diterima. Setelah kuesioner dipastikan valid dan reliable kemudian kuesioner dibagikan menggunakan laman elektronik google form dalam rentang waktu tiga minggu untuk mendapatkan respon dari responden yg sudah ditentukan. Rentang waktu yang digunakan untuk mendapatkan responden adalah dua minggu. Dari hasil penyebaran kuesioner didapatkan 118 responden yang telah mengisi dan menilai Website KRS Online Universitas Muhammadiyah Magelang. Tabel 3 menunjukkan sebaran dari jumlah sampel responden yang masuk dan menilai Website KRS Online tersebut. 
Tabel 3. Jumlah Sampel Responden

\begin{tabular}{|c|c|}
\hline Jenis Kelamin & Frekuensi \\
\hline $\begin{array}{c}\text { Laki-laki } \\
\text { Perempuan } \\
\text { Total }\end{array}$ & $\begin{array}{c}84 \\
34 \\
118\end{array}$ \\
\hline $\begin{array}{l}\text { Uji validitas dilakukan kembali } \\
\text { setelah semua data dari responden } \\
\text { terkumpul, hal ini menjadi perlu dilakukan } \\
\text { untuk mengetahui dan menguji kekuatan } \\
\text { kesimpulan dan inferensi dari hasil uji } \\
\text { untuk mendekati kebenaran (Sarwono, } \\
\text { 2013). Pengujian ini dilakukan dengan } \\
\text { mengetahui } r \text { hitung dari nilai item yang } \\
\text { ada. Jika nilai r hitung > nilai } r \text { tabel, maka } \\
\text { pertanyaan kelompok tersebut dapat } \\
\text { dianggap "Valid" (Rohman \& Kurniawan, } \\
\text { 2017). Nilai } r \text { Tabel pada penelitian ini } \\
\text { adalah 0,325 yang diperoleh dari tabel } r \\
\text { signifikasi untuk pengujian dua arah }\end{array}$ & $\begin{array}{l}\text { dengan nilai } 0,05 \text { dan dengan derajat } \\
\text { bebas n-2, maka dapat dikatakan valid. } \\
\text { C. Usability Testing } \\
\text { Setelah uji validitas dilakukan, maka } \\
\text { perhitungan statistik deskriptif dilakukan } \\
\text { untuk melihat hasil dari usability testing } \\
\text { yang dilakukan. Dalam perhitungan } \\
\text { statistik deskriptif ini, hasil rata-rata } \\
\text { usability testing yang dilakukan pada } \\
\text { Website KRS Online kemudian dibagi } \\
\text { menjadi lima kategori dan rentang } \\
\text { penliaian. Tabel } 4 \text { menunjukkan kategori } \\
\text { dan rentang penilaian Website. }\end{array}$ \\
\hline \multicolumn{2}{|c|}{ Tabel 4. Kategori dan Rentang Penilaian Website } \\
\hline Interval & Kategori \\
\hline $0<1$ & Sanqat Buruk \\
\hline $1<2$ & Cukup Buruk \\
\hline $2<3$ & Baik \\
\hline $3<4$ & Cukup Baik \\
\hline $4=<5$ & Sangat Baik \\
\hline
\end{tabular}

Bila nilai rata-rata usability testing berada pada rentang $0<1$ maka dapat dinyatakan Website tersebut termasuk ke dalam kategori yang sangat buruk, kemudian rentang nilai $1<2$ Website dikatakan memiliki penilaian cukup buruk, untuk rentang nilai $2<3$, Website dinilai cukup baik, rentang $3<4$ Website dikatakan cukup baik dan Website dinyatakan sangat baik bila penilaian berada pada rentang $4=<5$. Dari pengelompokan rentang tersebut dan dari hasil usability testing yang sudah dilakukan didukung dengan pengolahan data kualitatif dari hasil transcribing pertanyaan terbuka.

Tabel 5. Total Rata-Rata Tiap Indikator Usability

\begin{tabular}{ccc}
\hline Kode & Rata- rata & Rata-rata /indikator \\
\hline (A1) & 4,02 & \\
(A2) & 3,71 & 3,86 \\
(A3) & 3,91 & \\
(A4) & 3,84 & \\
(A5) & 3,85 & 3,97 \\
(B1) & 4,19 & \\
(B2) & 3,89 & \\
(B3) & 3,82 & 3,51 \\
(C1) & 3,47 & \\
(C2) & 3,56 & 3,30 \\
(C3) & 3,50 & \\
(D1) & 2,90 & \\
\hline
\end{tabular}




\begin{tabular}{ccc}
\hline Kode & Rata- rata & Rata-rata /indikator \\
\hline (D2) & 3,42 & \\
(D3) & 3,59 & \\
(E1) & 3,27 & \\
(E2) & 3,61 & 3,46 \\
(E3) & 3,47 & \\
(E4) & 3,50 & \\
\hline
\end{tabular}

Tabel 5 menampilkan hasil total rata-rata tiap indikator dari penilaian usability yang dilakukan. Dari hasil tersebut, Website KRS Online tersebut, didapatkan bahwa indikator memorability menjadi aspek yang memiliki penilaian paling tinggi, dengan nilai 3,97 yang berarti ada pada rentang cukup baik. Hal ini bisa dikatakan bahwa pengguna dapat dengan mudah mengingat dan mengetahui penggunaan dari Website KRS Online. Dilanjutkan pada peringkat kedua yaitu indikator learnability sebesar 3,86 yang berarti cukup baik, dan dapat diinterpretasikan bahwa pengguna Website KRS Online merasakan Website tersebut mudah dipelajari, baik dari sisi alur maupun navigasi yang disediakan oleh Website tersebut. Tidak hanya itu saja, tanpa adanya manual books atau petunjuk penggunaan, pengguna tetap bisa menjalankan Website KRS Online ini sebagaimana fungsinya.

Efficiency menjadi indikator ketiga dengan penilaian sebesar 3,51 yang berarti juga ada pada rentang cukup baik. Pengguna merasakan bahwa mereka mudah mendapatkan informasi yang ingin dicari hanya dengan melihat halaman awal pada Website. Tidak hanya itu saja, pengguna juga merasa mampu melakukan banyak kegiatan (melakukan akses) dengan waktu yang cepat. Selanjutnya adalah indikator satisfaction sebesar 3,46 yang juga termasuk dalam kategori cukup baik. Secara keseluruhan penggunaan Website KRS Online, pengguna merasakan bahwa dari sisi design dan antarmuka yang disediakan oleh Website tersebut membuat pengguna merasa nyaman. Selain itu, ekspektasi penguna terpenuhi ketika menggunakan Website KRS Online. Yang terakhir adalah indikator errors dengan nilai sebesar 3,30; masih masuk kedalam kategori cukup baik. Dalam mengatasi error yang ada, Website KRS Online dinilai oleh pengguna mampu memberikan notifikasi-notifikasi tertentu apabila terjadi error. Namun untuk beberapa kasus seringkali pengguna mendapati error tanpa notifikasi. Hal ini yang menyebabkan pengalaman pengguna dari sisi menghadapi error yang ada.

\section{SIMPULAN}

Fokus dan tujuan dari penelitian ini adalah mengevaluasi Website KRS Online yang ada pada perguruan tinggi dengan usability testing dan in depth interview untuk mengetahui sejauh mana kebergunaan dari sistem tersebut. Indikator yang digunakan untuk menilai atau mengevaluasi Website tersebut ada lima, yaitu learnability, memorability, efficiency, errors, dan satisfaction. Total sampel responden pada penelitian ini adalah sejumlah 118 orang. Metode uji yang digunakan pada penelitian ini meliputi uji validitas yang terdiri dari uji reliabilitas dan uji korelasi. Signifikansi nilai Alpha yang digunakan pada penelitian ini sebesar 0.05. Dari hasil uji validitas data yang dilakukan, seluruh indikator memiliki nilai diatas 0.05. Dari hasil uji reliabilitas seluruh pernyataan yang ada pada kuesioner juga memiliki nilai Cronbach's Alpha sebesar 0.93, yang berarti seluruh pernyataan sesuai. Hasil evaluasi menunjukkan bahwa dari kelima indikator yang ada Website KRS Online memiliki nilai paling tinggi pada indikator memorability sebesar 3.97 ini berarti bahwa Website KRS Online mudah diingat navigasi dan tata letaknya untuk mendapatkan informasi. Sedangkan untuk nilai terendah dari kelima indikator adalah pada indikator error dengan nilai sebesar 3 ini berarti bahwa pada Website KRS Online masih ditemukan banyak kesalahan atau error baik itu pada brokenlink, atau pada navigasi yang ada. 
Untuk penelitian selanjutnya supaya dapat dikombinasikan lagi dengan berbagai macam indikator, kemudian bisa diketahui korelasi antar indikator yang ada, sehingga dapat melihat indikator-indikator yang berpengaruh.

\section{DAFTAR PUSTAKA}

Al Faruqi, U. 2019. Future Service in Industry 5.0. Jurnal Sistem Cerdas, 2(1), 67-79.

Al-omar, K. 2018. Evaluating the Usability and Learnability of the "Blackboard" LMS Using SUS and Data Mining. 2018 Second International Conference on Computing Methodologies and Communication (ICCMC), (Iccmc), 386-390.

Az-zahra, H. M. 2018. Usability Evaluation of User Interface in Badan Narkotika Nasional East Java Province Website. 2018 International Conference on Sustainable Information Engineering and Technology (SIET), 262-265.

Binti, N., \& Rozali, N. 2015. Usability Testing on Government Agencies Web Portal: A Study on Ministry of Education Malaysia ( MOE ) Web Portal. 2015 9th Malaysian Software Engineering Conference (MySEC), 37-42.

Huang, L., \& Li, M. 2010. Research on C2C E-Commerce Website Usability Evaluation System Process of Empirical Research implementation of Empirical Research Analysis of Empirical Research. 2010 IEEE 11th International Conference on Computer-Aided Industrial Design \& Conceptual Design 1, 2, 1371-1374.

Jusoh, S. (n.d.). The Development of Usability Heuristics For Arabic MCommerce Applications. 2019 IEEE Jordan International Joint Conference on Electrical Engineering and Information Technology (JEEIT), 779-784.

Kaur, R. 2018. Comparative Study for Evaluating the Usability of Web Based Applications. 2018 4th International Conference on Computing Sciences (ICCS), 94-97.

Luo, Z., Wang, Y., Wang, P., \& Participants, A. 2018. Usability Study on Railway Self-service Terminal Interface for the Elderly. 2018 11th International Symposium on Computational Intelligence and Design (ISCID), 1, 157-160.

Mustafa, S. H., \& Al-Zoua'bi, L. F. 2008. Usability of the academic Websites of Jordan's universities an evaluation study. In Proceedings of the 9th International Arab Conference for Information Technology (pp. 31-40).

Nurhadryani, Y., Sianturi, S. K., \& Hermadi, I. Pengujian Usability untuk Meningkatkan Antarmuka Aplikasi Mobile Usability Testing to Enhance Mobile Application User Interface, 2(2010).

Qashlim, A., Prahasto, T., \& Gernowo, R. 2014. Evaluasi Human Machine Interface Menggunakan Kriteria Usability Pada Sistem E-learning Perguruan Tinggi, 2, 96-107.

Qiu, Y. F., Chui, Y. P., \& Helander, M. G. 2006. Usability Analysis of Mobile Phone Camera Software Systems, $1-6$.

Rohman, F., \& Kurniawan, D. 2017. Pengukuran Kualitas Website Badan Nasional Penanggulangan Bencana Menggunakan Metode WebQual 4.0. JITK (Jurnal IImu Pengetahuan Dan Teknologi Komputer), 3(1), 31-38.

Sarwono, J. 2013. Buku Pintar IBM SPSS Statistics 19. BOOK, Elex Media Komputindo.

Sauer, J., Sonderegger, A., Heyden, K., Biller, J., Klotz, J., \& Uebelbacher, A. 2019. Extra-laboratorial usability tests: An empirical comparison of remote and classical fi eld testing with lab testing. Applied Ergonomics, 74, 85-96.

Sensuse, D. I., Pudy, P., \& Sukmasetya, P. 2017. Improving e-Leaming through Knowledge Management.

Setiawan, A., Widyanto, R. A., Studi, P., Informatika, T., Teknik, F., Magelang, U. M., \& Bersama, P. H. 2018. Evaluasi Website Perguruan Tinggi Menggunakan Metode Usability Testing, 3(3), 295-299.

Sukmasetya, P., Santoso, H. B., \& Sensuse, D. I. 2018. Current EGovernment Public Service on User Experience Perspective in Indonesia. 
2018 International Conference on Information Technology Systems and Innovation (ICITSI), 159-164.

Tongco, M. D. C. 2007. Purposive sampling as a tool for informant selection. Ethnobotany Research and Applications, 5, 147-158.

Wang, J. Usability testing on a government training platform: A case study. 2010 2nd International Conference on Education Technology and Computer, 2, V2211-V2-214.

Zarish, S. S. 2019. Analyzing Usability of Educational Websites Using Automated Tools. 2019 International Conference on Computer and Information Sciences (ICCIS), 1-4.

Zhevlwh, W. K. H., Ehhq, K. D. V, Dqg, G., Ghshqgv, G., Lwv, R. Q., Dwwulexwhv, L. 2016. Analysis of Website Usability Evaluation Methods, 1043-1046. 